\title{
ANALISIS KEMAMPUAN MATEMATIKA SISWA SMK DALAM MENYELESAIKAN SOAL SISTEM PERSAMAAN LINEAR TIGA VARIABEL TIPE HOT
}

\author{
Oktovianus Mamoh ${ }^{1}$, Dominika L. Taus ${ }^{2}$, Fitriani $^{3}$ \\ ${ }^{1,2,3}$ Program Studi Pendidikan Matematika, Universitas Timor \\ Email: oktomamoh01@gmail.com
}

\begin{abstract}
Abstrak:
Penelitian ini bertujuan untuk mengetahui kemampuan matematika siswa SMK dalam menyelesaikan soal sistem persamaan linear tiga variabel tipe High Order Thinking (HOT). Jenis penelitian ini adalah penelitian deskriptif kualitatif. Metode pengumpulan data yang digunakan dalam penelitian berupa tes tertulis dan wawancara. Subjek penelitian ini adalah Sembilan siswa kelas XI Farmasi SMK St. Agustinus Kefamenanu, Provinsi Nusa Tenggara Timur. Wawancara dilakukan terhadap dua siswa berkemampuan matematika rendah, dua siswa berkemampuan matematika sedang, dan dua siswa berkemampuan matematika tinggi. Hasil penelitian menunjukkan siswa berkemampuan matematika tinggi dan siswa berkemampuan matematika sedang mampu mengerjakan soal pada tahap menganalisis dan mengevaluasi, tetapi belum sampai pada tahap mencipta karena siswa masih mengerjakan soal menggunakan cara yang dicontohkan guru. Siswa berkemampuan matematika rendah hanya mampu mengerjakan soal pada tahap menganalisis.
\end{abstract}

Kata Kunci: Kemampuan Matematika, Sistem Persamaan Linear Tiga Variabel (SPLTV), High Order Thingking (HOT)

\begin{abstract}
:
This study aimeds to determine the mathematical ability of vocational students in solving the HOT type three-variable linear equation system problems. This research was a qualitative descriptive study. The data collection methods were written tests and interviews. The subjects of this study were nine students of class XI Pharmacy, SMK St. Agustinus Kefamenanu, Province Nusa Tenggara Timur. Two students with low mathematical ability, two students with moderate mathematical ability, and twostudents with high mathematical ability were selected to be interviewed. The research suggest that, students with high mathematical ability and students with moderate mathematical ability are able to work on questions at the analyzing and, evaluating stage, but have not yet reached the creating stage. Students are still working on problems using the method given by the teacher. Students with low mathematical ability are only able to work on problems at the analyzing stage.
\end{abstract}

Keywords: : Mathematical Ability, Three Variable Linear Equation System (SPLTV), High Order Thingking (HOT)

\section{Pendahuluan}

Matematika adalah suatu alat untuk mengembangkan cara berpikir, sehingga matematika sangat diperlukan baik untuk kehidupan sehari-hari maupun dalam menghadapi kemajuan IPTEK yang membuat matematika perlu dibekalkan kepada setiap siswa sejak pendidikan dasar menurut Hudojo dalam (Sujoko \& Maulia, 2019: 674). Dalam matematika, banyak kemampuan yang dapat dimiliki oleh siswa, salah satunya kemampuan High Order Thinking. Higher Order Thinking Skill (HOTS) atau kemampuan berpikir tingkat tinggi yang berarti proses berpikir yang mengharuskan siswa untuk memanipulasi informasi yang ada atau ide-ide dengan cara tertentu yang memberikan mereka pengertian dan implikasi baru menurut Gunawan (Lailly \& Wisudawati, 2015: 28).

Menurut Indaryanti, dkk (2018: 81) siswa Indonesia cenderung menguasai soalsoal yang bersifat rutin, komputasi sederhana, yang menekankan aspek ingatan dan kurang melatih keterampilan berpikir tingkat tinggi siswa, serta mengukur pengetahuan terhadap fakta yang berkonteks keseharian. Karakteristik 
pembelajaran matematika saat ini lebih fokus pada kemampuan prosedural, komunikasi satu arah, pengaturan kelas monoton, low order thinking skill yang bergantung pada buku paket dan lebih dominan menyelesaikan soal rutin serta pertanyaan tingkat rendah (Lewy, 2011: 59), sehingga siswa cenderung bergantung pada penggunaan rumus-rumus matematika dalam memecahkan suatu masalah matematika. Dalam kurikulum 2013, mata pelajaran matematika diharapkan tidak hanya membekali siswa dengan kemampuan untuk menggunakan perhitungan atau rumus dalam mengerjakan soal tes saja akan tetapi juga mampu melibatkan kemampuan bernalar dan analitisnya dalam memecahkan masalah sehari-hari. Pemecahan masalah ini tidak semata-mata masalah yang berupa soal rutin akan tetapi lebih kepada permasalahan yang dihadapi sehari-hari (Suryapuspitarini, dkk, 2018: 877).

Menurut Anjani (2017: 3) kemampuan siswa dapat dikembangkan melalui pemberian soal matematika yang berbasis pada kejadian nyata (kontekstual). Soal-soal kontekstual akan melatih siswa untuk berpikir kritis, logis, dan sistematis dalam menyelesaikan masalah yang ada di kehidupan sehari-hari. Senada dengan itu, Mamoh (2017, 457) mengatakan, berpikir logis akan bisa menjadi kebiasaan berpikir keseharian jika dilakukan pembinaan berpikir logis secara terus menerus dan berkesinambungan. Ketika siswa berhasil menyelesaikan masalah berarti mereka telah belajar aturan baru yang lebih kompleks dari aturan-aturan yang ada sebelumnya. Aturan-aturan yang lebih kompleks inilah yang mendorong siswa untuk berpikir pada tingkatan berpikir yang lebih tinggi (High Order Thinking). Dimensi proses berpikir dalam Taksonomi Bloom sebagaimana yang telah disempurnakan oleh Anderson \& Krathwohl (2001), terdiri atas kemampuan: mengetahui (knowing-Cl), memahami (understanding-C2), menerapkan (aplyingC3), menganalisis (analyzing-C4), mengevaluasi (evaluating-C5), dan mengkreasi (creating-C6). Soal-soal HOT pada umumnya mengukur kemampuan pada ranah menganalisis (analyzing-C4), mengevaluasi (evaluating-C5), dan mengkreasi (creating-C6).

Materi sistem persamaan linear tiga variabel merupakan salah satu materi matematika yang dapat digunakan untuk melatih kemampuan berpikir tingkat tinggi, karena materi tersebut berkaitan langsung dengan kejadian-kejadian nyata di lingkungan sekitar (kontekstualisasi) dan pada umumnya soal pada materi sistem persamaan linear tiga variabel berupa soal cerita yang cukup panjang sehingga untuk menyelesaikan soal tersebut peserta didik juga harus melakukan analisis yang lebih mendalam terhadap soal.

Berdasarkan uraian latar belakang masalah di atas, dapat diidentifikasikan masalah yang muncul adalah bagaimana kemampuan matematika siswa SMK St. Agutinus Kefamenanu dalam menyelesaikan soal sistem persamaan linear tiga variabel tipe HOT ditinjau dari jawaban siswa?. Sejalan dengan rumusan masalah tersebut, maka tujuan dari penelitian ini adalah untuk mengetahui kemampuan matematika siswa SMK St. Agustinus Kefamenanu dalam menyelesaikan soal sistem persamaan linear tiga variabel tipe HOT ditinjau dari jawaban siswa.

\section{Metode Penelitian}

Jenis penelitian ini adalah penelitian deskriptif kualitatif. Dalam hal ini adalah bertujuan untuk mengetahui gambaran tentang kemampuan matematika siswa SMK St. Agustinus Kefamenanu dalam menyelesaikan soal sistem persamaan linear tiga variabel tipe higher order thingking (HOT). Tempat dan waktu penelitian yaitu di SMK St. Agustinus Kefamenanu Jln. Ahmad Yani Naesleu pada tanggal 14 september dan 16 september 2020. Subjek dalam penelitian ini adalah siswa kelas XI Farmasi yang berjumlah 9 orang, pemilihan subjek berdasarkan rekomendasi dari sekolah yang memilih 6 orang siswa, yaitu terdiri dari 2 orang siswa berkemampuan tinggi, 2 orang siswa berkemampuan sedang, dan 2 orang siswa berkemampuan rendah berdasarkan kriteria tingkat kemampuan matematika. 
Instrumen yang digunakan adalah soal tes uraian tipe HOT dan pedoman wawancara. Teknik pengumpulan data yang digunakan adalah tes, wawancara dan dokumentasi. Teknik analisis data yang digunakan adalah reduksi data, penyajian data dan penarikan kesimpulan.

\section{Hasil dan Pembahasan Hasil}

Dalam tahap ini akan dipaparkan beberapa data yang telah dilakukan di SMK St. Agustinus Kefamenanu. Terdapat dua bentuk data yang dideskripsikan yaitu hasil tes tertulis dan wawancara. Kedua data tersebut menjadi tolak ukur untuk mengetahui bagaimana kemampuan matematika siswa dalam menyelesaikan soal tipe HOT. Peneliti mengambil 6 siswa dari 9 siswa untuk diwawancarai. Berikut deskripsi 6 siswa yang dijadikan subjek dalam mengerjakan tes kemampuan matematika siswa dalam menyelesaikan soal tipe HOT.

1. Deskripsi Hasil Tes dan Wawancara Siswa yang Berkemampuan

Matematika Tinggi (AEML) pada Soal No 1 dan 2

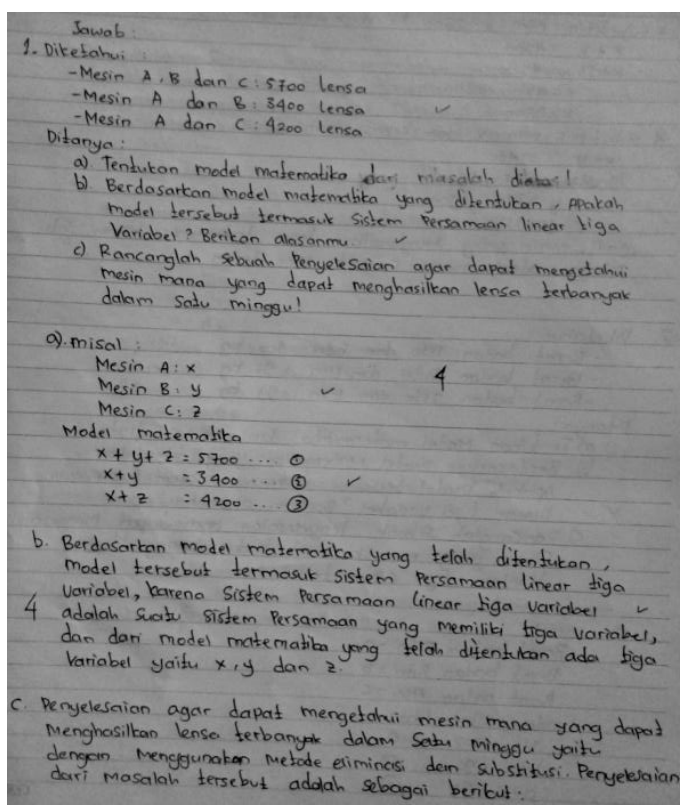

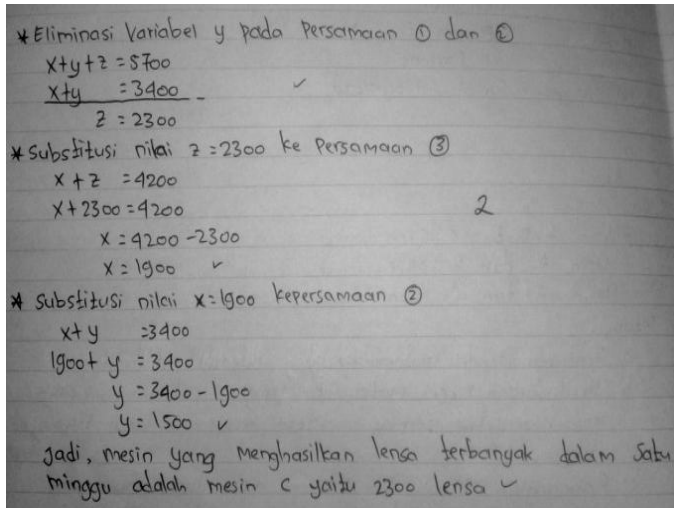

Gambar 1: Jawaban Siswa AEML pada Soal No 1

Dari hasil jawaban siswa AEML di atas, terlihat bahwa siswa AEML mampu mengerjakan soal nomor 1a. Siswa AEML mampu menentukan semua unsur yang ada pada soal nomor 1a (Diketahui, Ditanya, Pemisalan dan Model matematika) dengan benar. Sedangkan pada nomor $1 \mathrm{~b}$ siswa AEML mampu menjawab pertanyaan dengan benar disertai alasan yang tepat. Selanjutnya pada nomor 1c siswa AEML mampu mengerjakan soal tersebut menggunakan cara yang diajarkan guru dan jawaban benar.

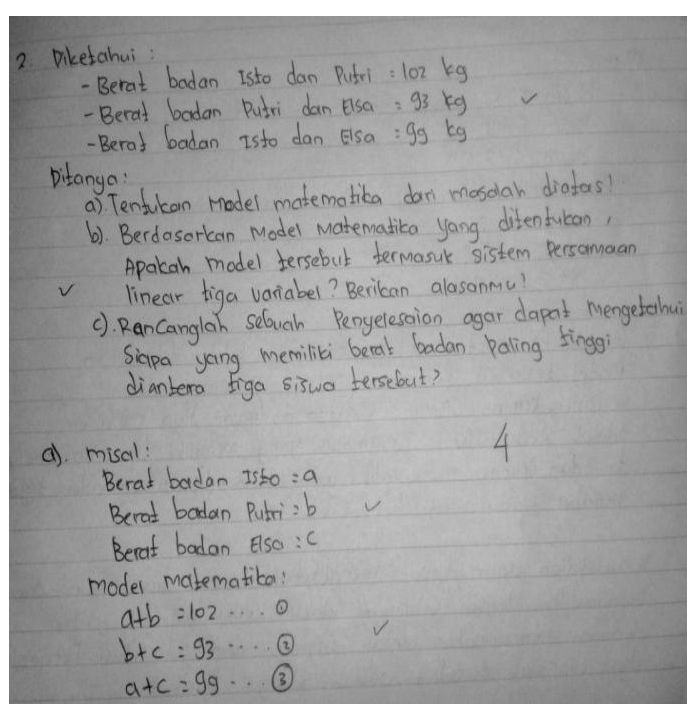




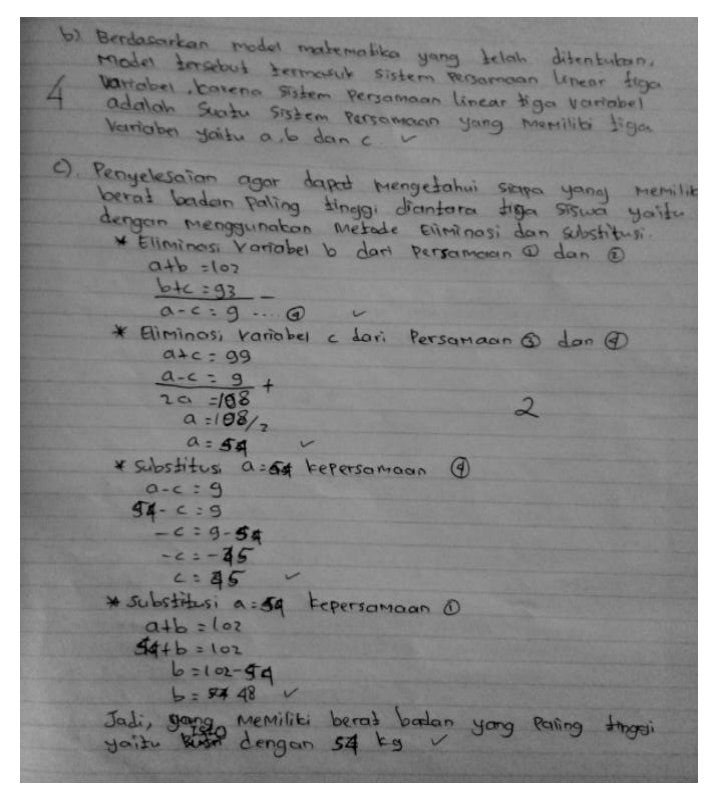

Gambar 2 : Jawaban Siswa AEML pada Soal No 2

Dari hasil jawaban siswa AEML pada soal nomor 2 di atas, terlihat bahwa siswa AEML juga mampu mengerjakan soal nomor 2a. Siswa AEML mampu menentukan semua unsur yang ada pada soal nomor 2a (Diketahui, Ditanya, Pemisalan dan Model matematika) dengan benar. Sedangkan pada nomor $2 \mathrm{~b}$ siswa AEML mampu menjawab pertanyaan dengan benar disertai alasan yang tepat. Selanjutnya pada nomor 2c siswa AEML mampu mengerjakan soal tersebut menggunakan cara yang diajarkan guru dan jawaban benar.

Dari hasil tes dan wawancara siswa yang berkemampuan matematika tinggi (AEML) pada soal no 1 dan 2 diketahui bahwa siswa AEML sudah mampu menyelesaikan soal 1a dan 2a (Tahap Menganalisis) dengan benar. Selanjutnya pada nomor $1 b$ dan $2 b$ (Tahap Mengevaluasi) siswa AEML juga mampu menjawab soal dengan benar. Sedangkan pada soal 1c dan 2c (Tahap Mencipta) siswa AEML masih mengerjakan soal menggunakan cara yang diberikan guru. Jadi pada soal nomor 1 dan 2, siswa AEML yang berkemampuan matematika tinggi mampu mengerjakan soal pada tahap menganalisis, mengevaluasi tetapi belum sampai pada tahap mencipta.
2. Deskripsi Hasil Tes dan Wawancara Siswa yang Berkemampuan Matematika Tinggi (MAKP) pada Soal No 1 dan 2

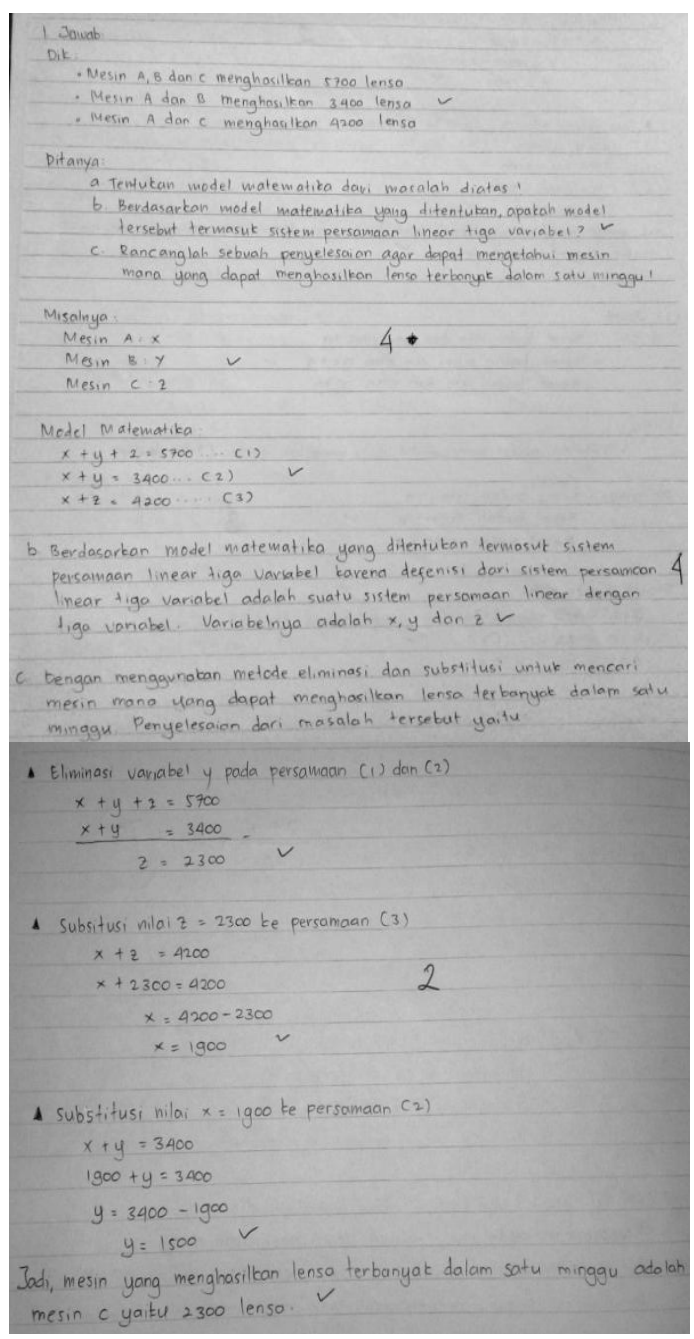

\section{Gambar 3 : Jawaban Siswa MAKP pada Soal No 1}

Dari hasil jawaban siswa MAKP di atas, terlihat bahwa siswa MAKP mampu mengerjakan soal nomor 1a. Siswa MAKP mampu menentukan semua unsur yang ada pada soal nomor 1a (Diketahui, Ditanya, Pemisalan dan Model matematika) dengan benar. Sedangkan pada nomor $1 \mathrm{~b}$ siswa MAKP mampu menjawab pertanyaan dengan benar disertai alasan yang tepat. Selanjutnya pada nomor 1c siswa MAKP mampu mengerjakan soal tersebut menggunakan cara yang diajarkan guru dan jawaban benar. 


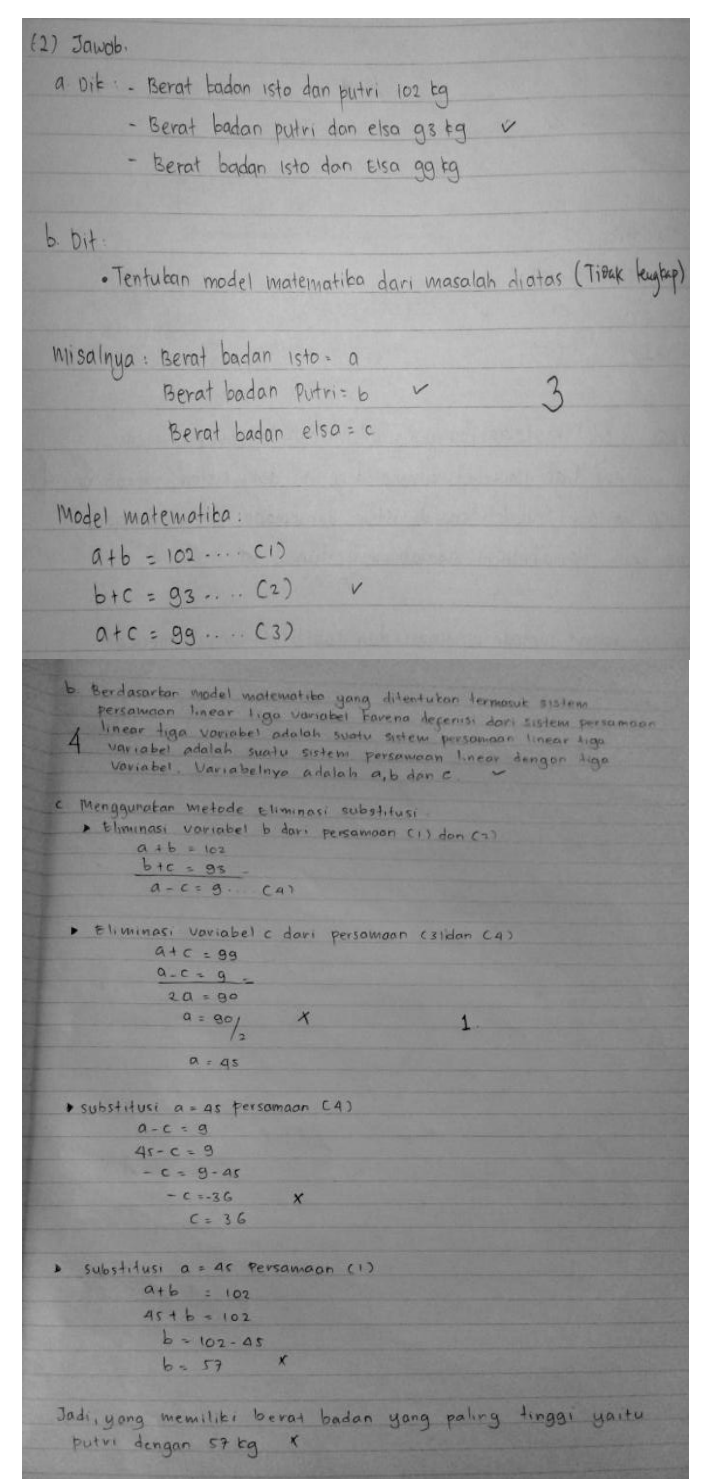

\section{Gambar 4 : Jawaban Siswa MAKP pada Soal No 2}

Dari hasil jawaban siswa MAKP pada soal nomor 2 di atas, terlihat bahwa siswa MAKP mampu mengerjakan soal nomor 2a. Siswa MAKP mampu menentukan semua unsur yang ada pada soal nomor 2a (Diketahui, Ditanya, Pemisalan dan Model matematika) dengan benar meskipun pada bagian ditanya kurang lengkap. Sedangkan pada nomor $2 b$ siswa MAKP mampu menjawab pertanyaan dengan benar disertai alasan yang tepat. Selanjutnya pada nomor 2c siswa MAKP mampu mengerjakan soal tersebut menggunakan cara yang diajarkan guru dan jawabannya masih kurang tepat.
Dari hasil tes dan wawancara siswa yang berkemampuan matematika tinggi (MAKP) pada soal no 1 dan 2 diketahui bahwa siswa MAKP sudah mampu menyelesaikan soal 1a dan $2 \mathrm{a}$ (Tahap Menganalisis) dengan benar meskipun pada nomor 2a bagian ditanya jawabannya kurang lengkap. Selanjutnya pada nomor $1 b$ dan 2b (Tahap Mengevaluasi) siswa MAKP juga mampu menjawab soal dengan benar. Sedangkan pada soal 1c dan 2c (Tahap Mencipta) siswa MAKP masih mengerjakan soal menggunakan cara yang diberikan guru. Jadi pada soal nomor 1 dan 2, siswa MAKP yang berkemampuan matematika tinggi mampu mengerjakan soal pada tahap menganalisis, mengevaluasi tetapi belum sampai pada tahap mencipta.

3. Deskripsi Hasil Tes dan Wawancara Siswa yang Berkemampuan Matematika Sedang (IB) pada Soal No 1 dan 2.

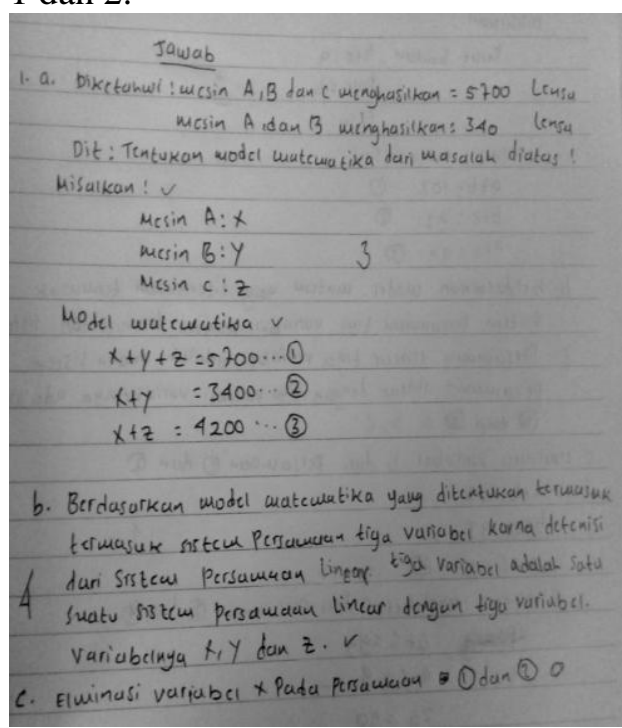

Gambar 5 : Jawaban Siswa IB pada Soal No 1

Dari hasil jawaban siswa IB di atas, terlihat bahwa siswa IB mampu mengerjakan soal nomor 1a. Siswa IB mampu menentukan tiga unsur yang ada pada soal nomor 1a (Diketahui, Pemisalan dan Model matematika) dengan benar meskipun pada bagian diketahui jawabannya kurang lengkap. Sedangkan pada nomor $1 \mathrm{~b}$ siswa IB mampu 
menjawab pertanyaan dengan benar disertai alasan yang tepat. Selanjutnya pada nomor 1c siswa IB tidak mengerjakan soal tersebut.

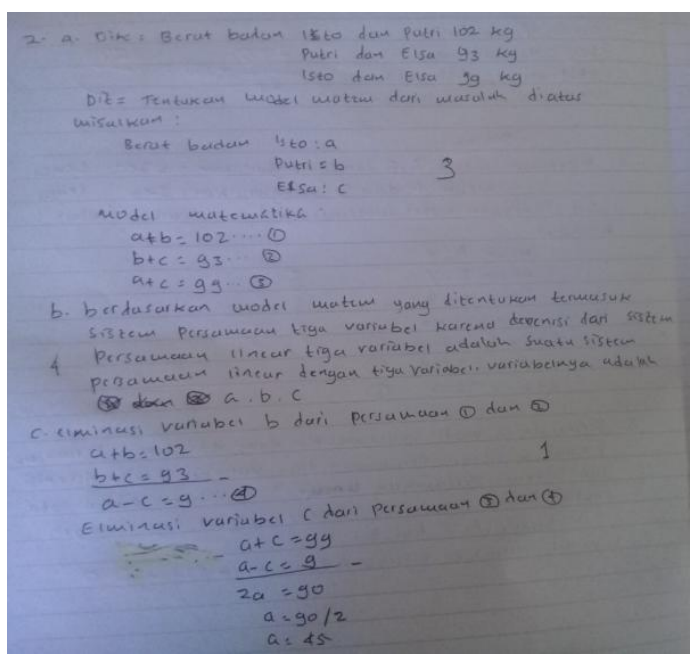

Gambar 6 : Jawaban Siswa IB pada Soal No 2

Dari hasil jawaban siswa IB pada soal nomor 2, terlihat bahwa siswa IB juga mampu mengerjakan soal nomor $2 \mathrm{a}$. Siswa IB mampu menentukan tiga unsur yang ada pada soal nomor 2a (Diketahui, Pemisalan dan Model matematika) dengan benar sedangkan pada bagian ditanya jawabannya tidak lengkap. Sedangkan pada nomor 2b siswa IB mampu menjawab pertanyaan dengan benar disertai alasan yang tepat. Selanjutnya pada nomor 2c siswa IB menyelesaikan soal tersebut menggunakan cara yang diberikan oleh guru tetapi jawabannya tidak lengkap dan masih kurang tepat.

Dari hasil tes dan wawancara siswa yang berkemampuan sedang (IB) pada soal nomo 1 dan 2 diketahui bahwa siswa IB sudah mampu menyelesaikan soal 1a dan 2a (Tahap Menganalisis) dengan benar meskipun pada soal 1a bagian diketahui siswa IB lupa menuliskan salah satu yang diketahui, dan pada bagian ditanya siswa IB hanya menuliskan satu dari tiga pertanyaan. Selanjutnya pada nomor $1 \mathrm{~b}$ dan $2 \mathrm{~b}$ (Tahap Mengevaluasi) siswa IB mampu menjawab soal dengan benar. Sedangkan pada soal $1 \mathrm{c}$ dan $2 \mathrm{c}$ (Tahap Mencipta) siswa IB berusaha untuk mengerjakan menggunakan cara yang diberikan guru tetapi siswa IB bingung mengerjakan. Jadi pada soal nomor 1 dan 2, siswa IB yang berkemampuan matematika sedang mampu mengerjakan soal pada tahap menganalisis, mengevaluasi tetapi belum sampai pada tahap mencipta.

4. Deskripsi Hasil Tes dan Wawancara Siswa yang Berkemampuan Matematika Sedang (ENU) pada Soal No 1 dan 2.

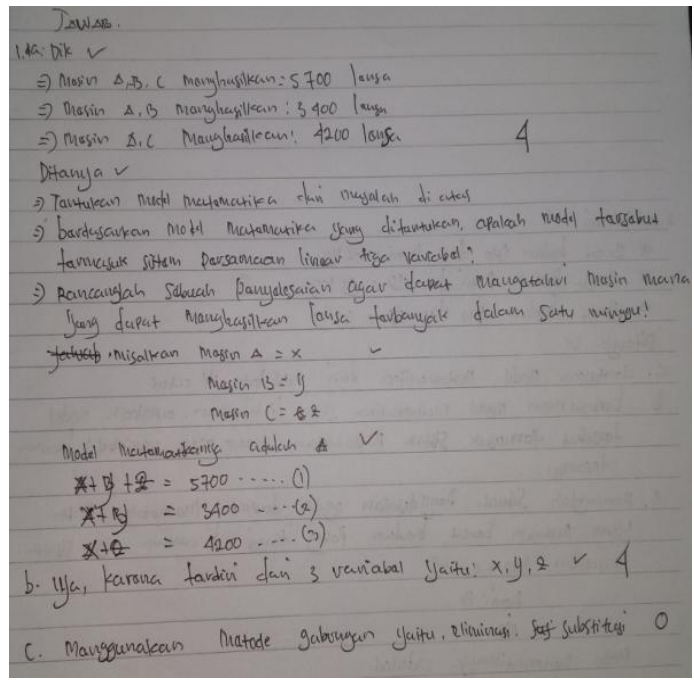

Gambar 7 : Jawaban Siswa ENU pada Soal No 1

Dari hasil jawaban siswa ENU di atas, terlihat bahwa siswa ENU mampu mengerjakan soal nomor 1a. Siswa ENU mampu menentukan semua unsur yang ada pada soal nomor 1a (Diketahui, Ditanya, Pemisalan dan Model matematika) dengan benar. Sedangkan pada nomor $1 \mathrm{~b}$ siswa ENU mampu menjawab pertanyaan dengan benar disertai alasan yang tepat. Selanjutnya pada nomor 1c siswa ENU tidak mengerjakan soal tersebut. 


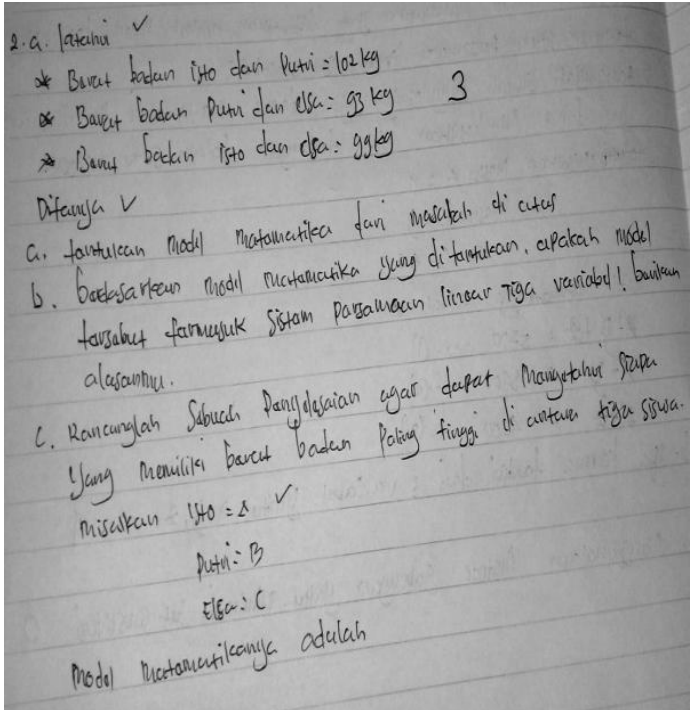

Gambar 8 : Jawaban Siswa ENU
pada Soal No 2

Dari hasil jawaban siswa ENU pada soal nomor 2 di atas, terlihat bahwa pada soal nomor 2 a siswa ENU hanya menuliskan apa yang diketahui, ditanya dan pemisalan. Sedangkan model matematikanya tidak lanjut dikerjakan. Selanjutnya pada nomor $2 \mathrm{~b}$ dan $2 \mathrm{c}$ siswa ENU tidak mengerjakan.

Dari hasil tes dan wawancara siswa yang berkemampuan matematika sedang (ENU) pada soal nomor 1 dan 2 diketahui bahwa siswa ENU sudah mampu menyelesaikan soal 1a dan 2a (Tahap Menganalisis) dengan benar meskipun pada soal 2a siswa ENU tidak membuat model matematikanya. Selanjutnya pada nomor 1b (Tahap Mengevaluasi) siswa ENU mampu menjawab soal dengan benar. Sedangkan pada soal $1 \mathrm{c}$ dan $2 \mathrm{c}$ (Tahap Mencipta) siswa ENU berusaha untuk mengerjakan menggunakan cara yang diberikan guru tetapi siswa ENU bingung mengerjakan. Jadi pada soal nomor 1 dan 2, siswa ENU yang berkemampuan matematika sedang mampu mengerjakan soal pada tahap menganalisis, mengevaluasi tetapi belum sampai pada tahap mencipta.

5. Deskripsi Hasil Tes Dan Wawancara Siswa Yang Berkemampuan Matematika Rendah (EKN) Pada Soal No 1 dan 2.

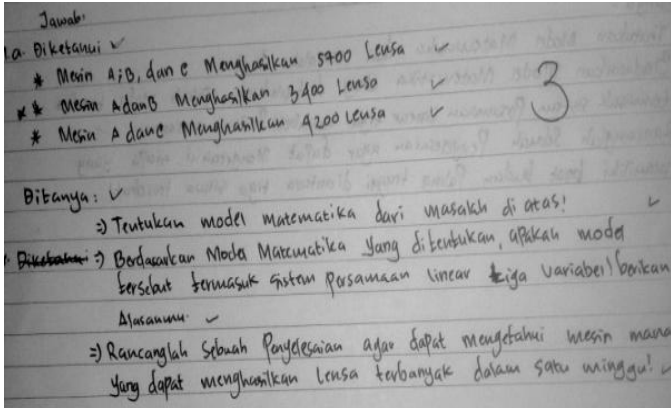

\section{Gambar 9: Jawaban Siswa EKN pada Soal No 1}

Dari hasil jawaban siswa EKN di atas, terlihat bahwa siswa EKN hanya mampu mengerjakan soal nomor 1a tetapi jawabannya belum lengkap. Siswa EKN hanya mampu menentukan dua unsur yang ada pada soal nomor 1a (Diketahui dan Ditanya). Siswa EKN tidak mampu menentukan pemisalan dan model matematika dari soal. Selanjutnya siswa tidak mengerjakan soal pada bagian $1 \mathrm{~b}$ dan 1c.

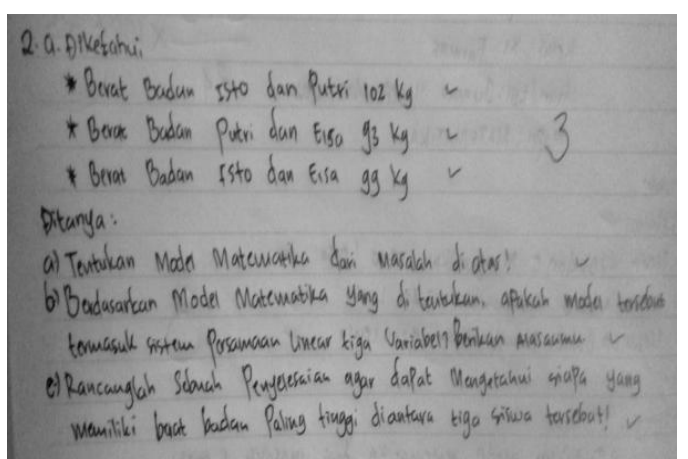

\section{Gambar 10: Jawaban Siswa EKN pada Soal No 2}

Dari hasil jawaban siswa EKN pada soal nomor 2, terlihat bahwa siswa EKN juga hanya mampu mengerjakan soal nomor 2a tetapi jawabannya belum lengkap. Siswa EKN hanya mampu menentukan dua unsur yang ada pada soal nomor 2a (Diketahui dan Ditanya). Siswa EKN tidak mampu menentukan pemisalan dan model matematika dari soal. Selanjutnya siswa tidak mengerjakan soal pada bagian $2 \mathrm{~b}$ dan $2 \mathrm{c}$.

Dari hasil tes dan wawancara siswa yang berkemampuan matematika rendah (EKN) pada soal nomor 1 dan 2 diketahui bahwa siswa kesulitan untuk 
menentukan pemisalan dan model matematika dikarenakan siswa sudah terbiasa dengan soal yang bersifat rutin. Disamping itu guru juga belum pernah mengenalkan pada siswa cara menentukan pemisalan dan model matematika dari soal cerita, meskipun soal-soal seperti itu sudah dikenalkan di SMP. Pada soal nomor 1 dan 2, siswa EKN yang berkemampuan matematika rendah hanya mampu mengerjakan soal pada tahap menganalisis meskipun jawabannya belum lengkap.

6. Deskripsi Hasil Tes Dan Wawancara Siswa Yang Berkemampuan Matematika Rendah (MFN) Pada Soal No 1 dan 2.

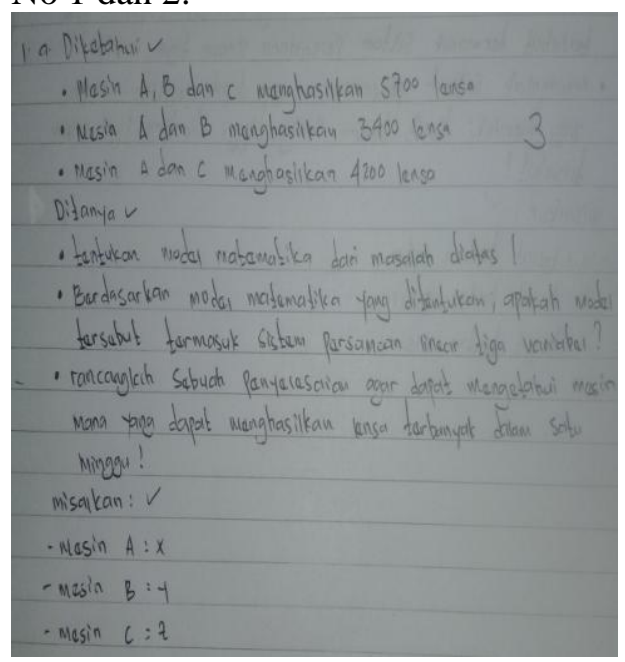

Gambar 11 : Jawaban Siswa MFN pada Soal No 1

Dari hasil jawaban siswa MFN di atas, terlihat bahwa siswa MFN hanya mampu mengerjakan soal nomor 1a tetapi jawabannya belum lengkap. Siswa MFN mampu menentukan dua unsur yang ada pada soal nomor 1a (diketahui,ditanya, pemisalan). Siswa MFN tidak mampu menentukan model matematika dari soal. Selanjutnya siswa tidak mengerjakan soal pada bagian $1 \mathrm{~b}$ dan $1 \mathrm{c}$.

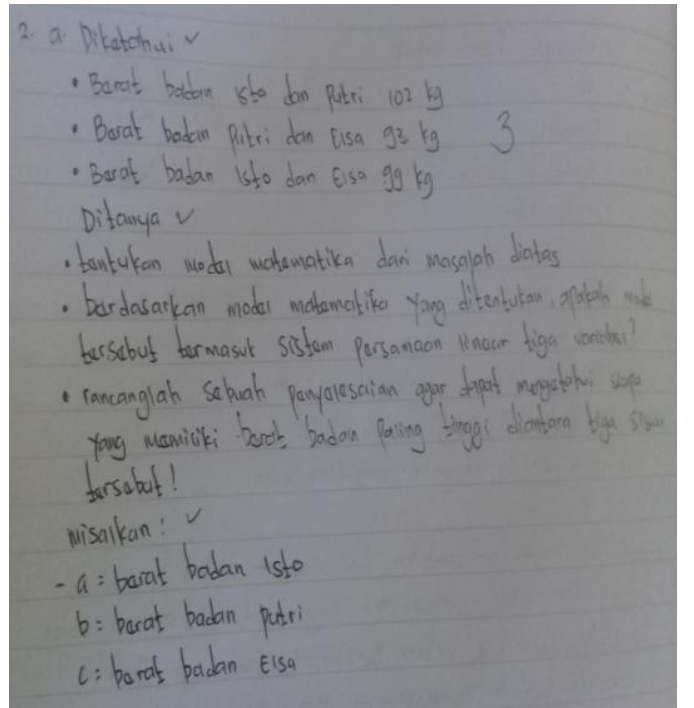

\section{Gambar 12 : Jawaban Siswa MFN} pada Soal No 2

Dari hasil jawaban siswa MFN pada soal nomor 2 di atas, terlihat bahwa siswa MFN juga hanya mampu mengerjakan soal nomor 2a tetapi jawabannya belum lengkap. Siswa MFN mampu menentukan dua unsur yang ada pada soal nomor 2a (diketahui,ditanya, pemisalan). Siswa MFN tidak mampu menentukan model matematika dari soal. Selanjutnya siswa tidak mengerjakan soal pada bagian $2 \mathrm{~b}$ dan $2 \mathrm{c}$.

Dari hasil tes dan wawancara siswa yang berkemampuan matematika rendah (MFN) pada soal nomor 1 dan 2 diketahui bahwa siswa kesulitan untuk menentukan model matematika dikarenakan siswa bingung padahal pemisalan yang dibuat sudah benar. Pada soal nomor 1 dan 2, siswa MFN yang berkemampuan matematika rendah hanya mampu mengerjakan soal pada tahap menganalisis meskipun jawabannya belum lengkap.

\section{Pembahasan}

Berdasarkan uraian data hasil tes dan wawancara di atas, maka diperoleh kemampuan matematika siswa dalam menyelesaikan soal sistem persamaan linear tiga variabel tipe HOT yang dikaji berdasarkan kategori kemampuan matematika siswa sebagai berikut:

Siswa AEML yang berkemampuan matematika tinggi pada 
penyelesaian soal sistem persamaan linear tiga variabel tipe HOT mampu mengerjakan soal nomor 1 dan nomor 2 pada tahap menganalisis, mengevaluasi tetapi belum sampai pada tahap mencipta. Dimana menurut Anderson dan Krathwohl (Anjani, 2017: 21) kemampuan yang termasuk HOT adalah kemampuan menganalisis, mengevaluasi dan mencipta, maka dalam menyelesaikan soal siswa AEML mampu menganalisis, mengevaluasi tetapi belum mampu mencipta karena pada tahap mencipta siswa AEML mengerjakan menggunakan metode gabungan (substitusi dan eliminasi) seperti yang diajarkan guru, siswa AEML tidak menggunakan cara selain yang diajarkan guru. Hasil penelitian relevan yang dilakukan oleh Mamoh, dkk (2020) menunjukkan bahwa baik siswa berkemampuan tinggi, sedang, maupun rendah tidak dapat menyelesaikan soal-soal yang membutuhkan kemampuan berpikir tingkat tinggi. Sebagian besar siswa yang diwawancarai menyatakan belum terbiasa menyelesaikan soal-soal yang membutuhkan kemampuan berpikir tingkat tinggi. Lalu hasil penelitian Deda, dkk (2020) menunjukkan bahwa siswa yang berkemampuan rendah hanya mampu menyelesaikan soal HOTS level menganalisis (C4) dan mengevaluasi (C5), sedangkan siswa berkemampuan sedang ternyata memiliki kemiripan dengan siswa yang berkemampuan tinggi, yaitu mampu menyelesaikan sebagian butir soal HOTS level menganalisis (C4), mengevaluasi (C5) dan mencipta (C6).

Selanjutnya siswa MAKP yang berkemampuan matematika tinggi juga pada penyelesaian soal sistem persamaan linear tiga variabel tipe HOT mampu mengerjakan soal nomor 1 dan nomor 2 pada tahap menganalisis, mengevaluasi tetapi belum sampai pada tahap mencipta. Dimana menurut Anderson dan Krathwohl (Anjani, 2017: 21) kemampuan yang termasuk HOT adalah kemampuan menganalisis, mengevaluasi dan mencipta, maka dalam menyelesaikan soal siswa MAKP mampu menganalisis, mengevaluasi tetapi belum mampu mencipta karena pada tahap mencipta siswa MAKP mengerjakan menggunakan metode gabungan (substitusi dan eliminasi) seperti yang diajarkan guru, siswa MAKP tidak menggunakan cara selain yang diajarkan guru. Hasil penelitian relevan yang dilakukan oleh Mamoh, dkk (2020) menunjukkan bahwa baik siswa berkemampuan tinggi, sedang, maupun rendah tidak dapat menyelesaikan soal-soal yang membutuhkan kemampuan berpikir tingkat tinggi. Sebagian besar siswa yang diwawancarai menyatakan belum terbiasa menyelesaikan soal-soal yang membutuhkan kemampuan berpikir tingkat tinggi. Lalu hasil penelitian Deda, dkk (2020) menunjukkan bahwa siswa yang berkemampuan rendah hanya mampu menyelesaikan soal HOTS level menganalisis (C4) dan mengevaluasi (C5), sedangkan siswa berkemampuan sedang ternyata memiliki kemiripan dengan siswa yang berkemampuan tinggi, yaitu mampu menyelesaikan sebagian butir soal HOTS level menganalisis (C4), mengevaluasi (C5) dan mencipta (C6).

Lalu siswa IB yang berkemampuan matematika sedang pada penyelesaian soal sistem persamaan linear tiga variabel tipe HOT mampu mengerjakan soal nomor 1 dan nomor 2 pada tahap menganalisis, mengevaluasi tetapi belum sampai pada tahap mencipta. Dimana menurut Anderson dan Krathwohl (Anjani, 2017: 21) kemampuan yang termasuk HOT adalah kemampuan menganalisis, mengevaluasi dan mencipta, maka dalam menyelesaikan soal siswa IB mampu menganalisis, mengevaluasi tetapi belum mampu mencipta karena pada tahap mencipta siswa IB tidak mengerjakan soal sama sekali. Hasil penelitian relevan yang dilakukan oleh Mamoh, dkk (2020) menunjukkan bahwa baik siswa berkemampuan tinggi, sedang, maupun rendah tidak dapat menyelesaikan soalsoal yang membutuhkan kemampuan berpikir tingkat tinggi. Sebagian besar siswa yang diwawancarai menyatakan belum terbiasa menyelesaikan soal-soal yang membutuhkan kemampuan berpikir tingkat tinggi. Lalu hasil penelitian Deda, dkk (2020) menunjukkan bahwa siswa yang berkemampuan rendah hanya mampu 
menyelesaikan soal HOTS level menganalisis (C4) dan mengevaluasi (C5), sedangkan siswa berkemampuan sedang ternyata memiliki kemiripan dengan siswa yang berkemampuan tinggi, yaitu mampu menyelesaikan sebagian butir soal HOTS level menganalisis (C4), mengevaluasi (C5) dan mencipta (C6).

Sedangkan siswa ENU yang berkemampuan matematika sedang juga pada penyelesaian soal sistem persamaan linear tiga variabel tipe HOT mampu mengerjakan soal nomor 1 dan nomor 2 pada tahap menganalisis, mengevaluasi tetapi belum sampai pada tahap mencipta. Dimana menurut Anderson dan Krathwohl (Anjani, 2017: 21) kemampuan yang termasuk HOT adalah kemampuan menganalisis, mengevaluasi dan mencipta, maka dalam menyelesaikan soal siswa ENU mampu menganalisis, mengevaluasi tetapi belum mampu mencipta karena pada tahap mencipta siswa ENU tidak mengerjakan soal sama sekali. Hasil penelitian relevan yang dilakukan oleh Mamoh, dkk (2020) menunjukkan bahwa baik siswa berkemampuan tinggi, sedang, maupun rendah tidak dapat menyelesaikan soal-soal yang membutuhkan kemampuan berpikir tingkat tinggi. Sebagian besar siswa yang diwawancarai menyatakan belum terbiasa menyelesaikan soal-soal yang membutuhkan kemampuan berpikir tingkat tinggi. Lalu hasil penelitian Deda, dkk (2020) menunjukkan bahwa siswa yang berkemampuan rendah hanya mampu menyelesaikan soal HOTS level menganalisis (C4) dan mengevaluasi (C5), sedangkan siswa berkemampuan sedang ternyata memiliki kemiripan dengan siswa yang berkemampuan tinggi, yaitu mampu menyelesaikan sebagian butir soal HOTS level menganalisis (C4), mengevaluasi (C5) dan mencipta (C6).

\section{Simpulan dan Saran Simpulan}

Berdasarkan hasil penelitian dan pembahasan dapat disimpulkan bahwa siswa yang berkemampuan matematika tinggi mampu menyelesaikan soal tipe HOT pada tahap menganalisis dan mengevaluasi tetapi belum sampai tahap mencipta karena siswa meyelesaikan soal masih menggunakan cara yang diajarkan guru, siswa belum mampu menggunakan cara penyelesaian selain yang diajarkan guru dengan benar, sedangkan siswa yang berkemampuan matematika sedang memiliki kemiripan dengan siswa yang berkemampuan matematika tinggi, yaitu mampu menyelesaikan soal tipe HOT pada tahap menganalisis dan mengevaluasi tetapi belum sampai tahap mencipta karena siswa tidak menyelesaikan soal sama sekali, selanjutnya siswa yang berkemampuan matematika rendah hanya mampu menyelesaikan soal pada tahap menganalisis.

\section{Saran}

Lewat hasil penelitian ini, peneliti mengharapkan agar sekolah yang merupakan lokasi penelitian dan SMK yang lainnya dapat menggunakan hasil penelitian ini sebagai informasi dalam kegiatan pembelajaran terutama untuk melatih para siswa berpikir tingkat tinggi.

\section{Ucapan Terima Kasih}

Terima kasih kepada SMK St Agustinus Kefamenanu sebagai lokasi penelitian.

\section{Daftar Pustaka}

Anderson, L. W., \& Krathwohl, D. R. (2001). Kerangka Landasan untuk Pembelajaran, Pengajaran, dan Asesmen Agung Prihantoro(penerjemah). Yogyakarta: Pustaka Pelajar.

Anjani, Y. F. (2017). Analisis Kemampuan Berpikir Tingkat Tinggi Menurut Teori Anderson dan Krathwohl Pada Peserta Didik Kelas XI Bilingual Class System MAN 2 Kudus pada Pokok Bahasan Program Linier. Semarang, Universitas Islam Negeri Walisongo : Skripsi.

Deda, Y.N., Ratu, A.H., Amsikan, S., \& Mamoh, O. (2020). Analisis Kemampuan Siswa dalam Menyelesaikan Soal Ujian 
Nasional Matematika SMP/MTS Berdasarkan Perspektif Higher Order Thinking Skills (HOTS). Jurnal Pendidikan Matematika. 3(1), 1-6. https://doi.org/10.30598/jupitekvo 13iss1pp1-6

Indaryanti, Scristia, \& Meryansumayeka. (2018). Analisis Konsepsi Guru Matematika Sekolah Menengah terhadap High Order Thinking Skill (HOTS). Prosiding Seminar Nasional dan Lokakarya PISA (hal. 80-91). Palembang, Indonesia

Lailly, N. R., \& Wisudawati, A. W. (2015). Analisis Soal Tipe Higher Order Thingking Skill (HOTS) dalam Soal UN Kimia SMA Rayon B Tahun 2012/2013. Jurnal Kaunia, 11(1), 27-39

Lewy, L. (2011). Pengembangan Soal untuk Mengukur Kemampuan Berpikir Tingkat Tinggi Pokok Bahasan Barisan dan Deret Bilangan di Kelas IX Akselerasi SMP Xaverius Maria Palembang. Jurnal Pendidikan Matematika, 5(1), 58-73
Mamoh, O., (2017) Meningkatkan Prestasi

Belajar Matematika Melalui Pembinaan Berpikir Logis dalam Pembelajaran pada Siswa SMP. Prosiding KNPMP II Surakarta 455-464

Mamoh, O., Luan, F., \& Bete, H. (2020). Analisis Kemampuan Berpikir Tingkat Tinggi Siswa SMP Timor Tengah Utara dalam Menyelesaikan Soal Materi Aljabar. SIGMA. 6(1), 87-97

Sujoko., \& Maulia, V. O. (2019). Analisis Kesalahan Siswa dalam Menyelesaikan Soal Cerita Materi Sistem Persamaan Linear Tiga variabel Berdasarkan Analisis Newman Kelas X SMA Intensif Taruna Pembangunan Surabaya. Prosiding Seminar Nasional Pendidikan Matematika (SNPM) (hal. 674-681)

Suryapuspitarini, B., Wardono., \& Kartono. (2018). Analisis Soal-Soal Matematika Tipe Higher Order Thinking Skill (HOTS) pada Kurikulum 2013 untuk Mendukung Kemampuan Literasi Siswa. Journal unnes, (876-884). https://journal.unnes.ac.id/sju/inde x.php/prisma/ 